\title{
Editorial
}

\section{Ten years after the crash: what have we learned?}

\author{
Jan Behringer \\ Macroeconomic Policy Institute, Hans Böckler Foundation, Düsseldorf, Germany \\ Sebastian Gechert \\ Macroeconomic Policy Institute, Hans Böckler Foundation, Düsseldorf, Germany \\ Özlem Onaran \\ Greenwich Political Economy Research Centre, University of Greenwich, London, UK \\ Miriam Rehm \\ University of Duisburg-Essen, Germany
}

In September 2008 the bankruptcy of Lehman Brothers was a landmark in a series of events that triggered the global financial and economic crisis. However, its roots lie much deeper: rising inequality, deregulation of financial markets, private debt and trade imbalances have all played a role. Ten years later, financial markets again reached record highs, the world economy grew at a strong pace and major central banks began tightening their monetary policy stance. On the other hand, the gains accrued largely to a small elite, even limited regulatory achievements have come under attack, and right-wing populism is threatening democracy in high-income countries, while many low-income countries still struggle with the fallouts from war and poverty. What did societies and politicians learn from the crash? Has capitalism become more stable, and more resilient in the face of unhealthy dynamics? What are the theoretical achievements in orthodox and heterodox economic thinking since the crisis? Where do we go from here?

As in recent years, the European Journal of Economics and Economic Policies: Intervention documents the contributions to the plenary sessions of the latest conference of the Forum for Macroeconomics and Macroeconomic Policies, which took place from 25 to 27 October 2018 in Berlin. The papers and proceedings evaluate the impact of the financial crisis on macroeconomic thinking and macroeconomic policies and try to make some predictions for the years to come.

Engelbert Stockhammer's contribution asks why the mainstream has not been shaken more strongly since 2008, by the crisis which has laid bare its failures. One reason might be the lack of a canonical alternative model, for which Stockhammer then lays out substantial parts. He sees the integration of distributional Kaleckian models with financial Minskyan models including a supply-side analysis as strong contenders against orthodox modelling. After tracing the broad developments of the post-Keynesian theoretical debate since the crisis, Stockhammer describes the pseudo-Goodwin cycles that arise from such a Kalecki-Minsky model, that is, counter-clockwise movements in a distribution-output space which are not driven by profit-led/forced saving mechanisms. Furthermore, Stockhammer cites empirical evidence for such endogenous debt cycles, which emerge from the interaction of financial and real variables - however, just for business and not household debt. This suggests that institutional set-ups do play a role in determining the effect of wage- or (pseudo-) profit-led regimes. This is particularly the case with regard to real estate prices, whose speculative 
dynamics in Stockhammer's view cast doubt on the presence of consumption cascades. He concludes from this research that speculative dynamics in house prices affect real economic activity, with important implications for monetary and regulatory policies.

Stephanie Seguino investigates post-Keynesians' and feminist macroeconomics' analyses of the crisis since 2008. She notes that they share a strong focus on inequality, albeit with a different bent: whereas post-Keynesians analyse the functional income distribution, feminist economists (and stratification economists) work on inequality between groups, for example, by race and gender. Regarding macroeconomics, feminist economics adds an analysis of social reproduction. Seguino shows that these additions are particularly relevant for an understanding of the crisis since 2008. For instance, Seguino discusses the downward harmonisation of men's well-being compared to that of women's, and the gendered and class-specific lending practices prior to the crisis. She illustrates the differential impact of the crisis on the unemployment rates of different groups: In the US, black and Hispanic men were hit harder than whites, and single mothers suffered more than married men or women; and in Europe, the foreign-born were impacted more severely than natives. She distils three lessons that feminist economics derived from the crisis: First, spending cuts and economic instability negatively affect human development and productivity in the long run through a number of channels: women's incomes fall more after austerity, which lowers investment in children. Second, it is possible to reduce inter-group inequalities through public investment, since women and lowincome groups benefit more from public expenditures on social infrastructure. Third, feminist economics calls for a role reversal of fiscal and monetary policy, whereby monetary policy should focus on the real economy and (un-)employment, and fiscal policy should address supply-side causes of inflation. Seguino thus shows that there is much common ground, and even more complementarity, between post-Keynesian macroeconomics and feminist economics.

The contribution by Thomas Reininger, Helene Schuberth and Michael Wögerer focuses on monetary policy. They discuss the changes in the global monetary order after the global financial crisis. The authors show that the decline in cross-border bank flows does not point to widely expected financial deglobalisation but rather to cross-border deleveraging of (core) European banks to restore their capital position. They argue that, despite remarkable post-crisis regulatory reforms especially in the banking system, opportunities for a more fundamental overhaul of the regulatory regime have not been seized.

László Andor presents a critical assessment of how the monetary union was designed, implemented and reformed in the European Union and discusses the risks of a slow-motion reform process. He argues that the fact that the euro area economy has recovered in the last few years has become a source of complacency and delays. In particular, he illustrates that powerful forces continue to downplay the importance of systemic reconstruction, and argues that the risk of disintegration remains high despite the relative tranquillity of markets in the 2014-2018 period. He concludes by evaluating competing paradigms about the eurozone crisis and the pros and cons of fiscal capacity building. 


\section{MARX, KEYNES AND THE POST-KEYNESIANS}

\section{Eckhard Hein}

Berlin School of Economics and Law, Institute for International Political Economy (IPE), Germany

In 2018 we not only evaluated the lessons learnt, or not learnt, ten years after the financial and economic crisis which started in 2008, we also celebrated the 200th birthday of Karl Marx, the eminent German philosopher, economist and political activist. That was the reason why Jan Priewe, an FMM fellow and member of the coordination committee, organised a special session for the 22nd FMM conference on the relevance of Marx's economics. The editors of the European Journal of Economics and Economic Policies: Intervention have decided to include three papers from this session in the current issue, focusing on the relationship between Marx, Keynes and the post-Keynesians.

Asking the provocative question of whether Marx was an early post-Keynesian, Eckhard Hein compares Marx's economics with those by Sraffa, Keynes, Kalecki and Minsky. First, the relationship between Marx's theory of value and Sraffa's reformulation of the classical theory of prices and distribution is reviewed. Second, the relationship between Marx's and Keynes's monetary theory is examined, relying on an interpretation of Marx's theory of value as a 'monetary theory of value'. Third, some light is shed on the Marx-Kalecki connection, focusing on Marx's theory of simple and extended reproduction and the built-in, although not fully elaborated, 'principle of effective demand' and the related theories of distribution and accumulation. Fourth and finally, Marx's and Minsky's views on financial instability and crises are scrutinised. Hein concludes that Marx should not be considered as an 'early post-Keynesian' but rather as an important forerunner of modern post-Keynesianism, with certain similarities, but also some important differences, and several areas of compatibility.

In his contribution on 'Marx and Keynes: from exploitation to employment', Fritz Helmedag argues that Marx's and Keynes's analyses of capitalism complement each other. In a largely general model including the public sector and international trade he attempts to show that the labour theory of value provides a sound foundation to reveal the factors influencing employment. Workers buy 'necessaries' out of their disposable wages from an integrated basic sector, whereas the revenues of the 'luxury' department spring from other sources of income. In order to maximise profits, the wage-good industry controls the level of unit labour costs. After all, effective demand governs the level of output and employment. On this basis, Helmedag derives implications for economic policy.

Finally, Hansjörg Herr examines Marx's theory of income distribution from a Keynesian and Kaleckian perspective. In Marx's explanation of functional income distribution, wages are given as a basket of goods required for the reproduction of the working class. Profits are then the remaining part of income created. According to Herr, Marx's explanation of functional income distribution has several theoretical and practical shortcomings. The Keynesian paradigm in the tradition of the original Keynes and Kalecki, however, provides alternative explanations of functional income distribution. Here the profit rate is given by processes in the financial market and by the degree of financialisation. Also the degree of monopoly may influence functional income distribution. The Keynesian and Kaleckian approaches allow for a plausible interpretation of the changes in functional income distribution during recent decades, according to Herr. 